\title{
Effects of replacing lactose from milk replacer by glucose, fructose, or glycerol on energy partitioning in veal calves
}

\author{
M. S. Gilbert, ${ }^{* 1}$ A. J. Pantophlet, † J. J. G. C. van den Borne, ${ }^{*}$ W. H. Hendriks, ${ }^{*}$ H. A. Schols, $\ddagger$ \\ and W. J. J. Gerrits* \\ ${ }^{*}$ Animal Nutrition Group, Wageningen University, PO Box 338, $6700 \mathrm{AH}$, Wageningen, the Netherlands \\ †Department of Pediatrics, Center for Liver, Digestive and Metabolic Diseases, University Medical Centre Groningen, PO Box 30001 , \\ 9700 RB Groningen, the Netherlands \\ łLaboratory of Food Chemistry, Wageningen University, PO Box 17, 6700 AA, Wageningen, the Netherlands
}

\section{ABSTRACT}

Calf milk replacers contain 40 to $50 \%$ lactose. Fluctuating dairy prices are a major economic incentive to replace lactose from milk replacers by alternative energy sources. Our objective was, therefore, to determine the effects of replacement of lactose with glucose, fructose, or glycerol on energy and protein metabolism in veal calves. Forty male Holstein-Friesian calves (114 $\pm 2.4 \mathrm{~kg}$ ) were fed milk replacer containing $46 \%$ lactose $(\mathrm{CON})$ or $31 \%$ lactose and $15 \%$ of glucose (GLUC), fructose (FRUC), or glycerol (GLYC). Solid feed was provided at $10 \mathrm{~g}$ of dry matter $(\mathrm{DM}) / \mathrm{kg}$ of metabolic body weight $\left(\mathrm{BW}^{0.75}\right)$ per day. After an adaptation of 48 $\mathrm{d}$, individual calves were harnessed, placed in metabolic cages, and housed in pairs in respiration chambers. Apparent total-tract disappearance of DM, energy, and $\mathrm{N}$ and complete energy and $\mathrm{N}$ balances were measured. The GLUC, FRUC, and GLYC calves received a single dose of $1.5 \mathrm{~g}$ of $\left[\mathrm{U}_{-}{ }^{13} \mathrm{C}\right]$ glucose, $\left[\mathrm{U}_{-}{ }^{13} \mathrm{C}\right]$ fructose, or [U$\left.{ }^{13} \mathrm{C}\right]$ glycerol, respectively, with their milk replacer at $0630 \mathrm{~h}$ and exhaled ${ }^{13} \mathrm{CO}_{2}$ and ${ }^{13} \mathrm{C}$ excretion with feces was measured. Apparent total-tract disappearance was decreased by $2.2 \%$ for DM, $3.2 \%$ for energy, and $4.2 \%$ for $\mathrm{N}$ in FRUC compared with CON calves. Energy and $\mathrm{N}$ retention did not differ between treatments, and averaged $299 \pm 16 \mathrm{~kJ} / \mathrm{kg}$ of $\mathrm{BW}^{0.75}$ per day and 0.79 $\pm 0.04 \mathrm{~g} / \mathrm{kg}$ of $\mathrm{BW}^{0.75}$ per day, respectively, although FRUC calves retained numerically less $\mathrm{N}(13 \%)$ than other calves. Recovery of ${ }^{13} \mathrm{C}$ isotopes as ${ }^{13} \mathrm{CO}_{2}$ did not differ between treatments and averaged $72 \pm 1.6 \%$. The time at which the maximum rate of ${ }^{13} \mathrm{CO}_{2}$ production was reached was more than $3 \mathrm{~h}$ delayed for FRUC calves, which may be explained by a conversion of fructose into other substrates before being oxidized.

Received July 4, 2015.

Accepted October 12, 2015

${ }^{1}$ Corresponding author: myrthe.gilbert@wur.nl
Recovery of ${ }^{13} \mathrm{C}$ in feces was greater for FRUC calves $(7.7 \pm 0.59 \%)$ than for GLUC $(1.0 \pm 0.27 \%)$ and GLYC calves $(0.5 \pm 0.04 \%)$, indicating incomplete absorption of fructose from the small intestine resulting in fructose excretion or fermentation. In conclusion, energy and $\mathrm{N}$ retention was not affected when replacing $>30 \%$ of the lactose with glucose, fructose, or glycerol. Increased fecal losses of DM, energy, and $\mathrm{N}$ were found in FRUC calves compared with CON, GLUC, and GLYC calves. Postabsorptive losses occurred with the urine for glucose and glycerol, which caused a lower respiratory quotient for GLUC calves during the night. Fructose was oxidized more slowly than glucose and glycerol, probably as a result of conversion into other substrates before oxidation.

Key words: veal calf, glucose, fructose, glycerol, energy retention

\section{INTRODUCTION}

Calf milk replacers (MR) contain 40 to $50 \%$ lactose. Apparent ileal lactose disappearance is high in milk-fed calves, up to or exceeding $97 \%$ of intake (Coombe and Smith, 1974; Gilbert et al., 2015a). High and fluctuating dairy prices are a major economic incentive to replace lactose from MR by alternative energy sources. It has been recently demonstrated that starch products are not suitable for replacing lactose, as maltase activity likely limits starch digestion and the vast majority of ingested starch products from MR disappears from the intestinal tract by fermentation rather than after hydrolysis by animal enzymes and subsequent absorption of glucose (Gilbert et al., 2015a,b). Therefore, energy sources that do not require enzymatic hydrolysis before absorption from the intestinal lumen might be more suitable lactose replacers. Glucose, fructose, and glycerol are potential lactose replacers. The small intestinal lumen absorbs glucose and fructose by specific carriers [i.e., glucose by $\mathrm{Na}^{+}$-dependent glucose transporter (SGLT1; Hediger and Rhoads, 1994; Zhao et al., 1998) 
and fructose by the facilitative glucose transporter GLUT5 (Burant et al., 1992; Zhao et al., 1998)]. Glycerol is easily absorbed from the small intestinal lumen, with $78 \%$ of the glycerol absorbed within 25 min after infusion in isolated loops of the small intestine of rats (Höber and Höber, 1937). There are indications that $\mathrm{Na}^{+}$-dependent carriers are also involved in the absorption of glycerol (Kato et al., 2005).

Ingestion of glucose, fructose, or glycerol by milk-fed calves results in the luminal presence of different (ratios of) monosaccharides and glycerol compared with the ingestion of lactose. Lactose is split into equimolar amounts of glucose and galactose by the brush-border enzyme lactase (Coombe and Smith, 1973). Lactase activity is high in milk-fed calves (Toofanian et al., 1973; Le Huerou et al., 1992; Gilbert et al., 2015a). Glucose is preferentially absorbed from the small intestine over galactose (Coombe and Smith, 1973), and replacing lactose with glucose might result in a greater postprandial blood glucose concentration, which could result in an increased excretion of glucose via urine when the renal threshold is exceeded (Hostettler-Allen et al., 1994; Vicari et al., 2008a). Feeding a fructose solution to milk-fed calves results in a low reducing sugar response in blood sampled from the jugular vein (Velu et al., 1960; Siddons et al., 1969). This result suggests either a rapid uptake of fructose by the liver from hepatic portal blood, as seen in rats and humans (as reviewed by Mayes, 1993), and subsequent postabsorptive conversion of fructose into products other than reducing sugars (i.e., glycogen, lactate, $\mathrm{CO}_{2}$ ), or a low absorption of fructose from the intestinal lumen. The latter might result in incomplete disappearance of fructose from the small intestine, resulting in substrate fermentation. Almost no increase in plasma glucose was found after feeding glycerol with an oral rehydration solution to 3-wk-old Swedish Red calves (Werner-Omazic et al., 2013). Feeding fructose or glycerol, therefore, probably results in a lower postprandial increase in glucose compared with lactose feeding. Also, fructose does not elicit insulin release (Curry, 1989). Feeding glycerol or glucose to 3-wk-old Swedish Red calves resulted in similar increases in plasma insulin, whereas plasma glucose levels were lower after glycerol feeding (Werner-Omazic et al., 2013). Glycerol or fructose feeding might, therefore, affect the insulin-to-glucose ratio and, consequently, alter glucose metabolism compared with lactose feeding. Also, heavier milk-fed calves often develop insulin resistance (Hostettler-Allen et al., 1994; Hugi et al., 1997) and replacing lactose might affect the development of insulin resistance.

Replacing lactose with glucose, fructose, or glycerol not only results in the luminal presence of different (ratios of) monosaccharides and glycerol, but could po- tentially alter glucose homeostasis and, thereby, energy partitioning. The objective of our study was to determine the effects of replacement of lactose with glucose, fructose, or glycerol on energy and protein metabolism in veal calves. The effects on glucose homeostasis and insulin sensitivity are presented elsewhere [A. Pantophlet, M. Gilbert, J. van den Borne, W. Gerrits, H. Roelofsen (Medical Biomics, University Medical Centre Groningen, Groningen, the Netherlands), M. Priebe (Department of Pediatrics; Center for Liver, Digestive and Metabolic Diseases, University Medical Centre Groningen, Groningen, the Netherlands), and R. Vonk (Medical Biomics, University Medical Centre Groningen, Groningen, the Netherlands), unpublished data].

\section{MATERIALS AND METHODS}

This experiment was approved by the Animal Care and Use Committee and conducted at the research facilities of Wageningen University.

\section{Animals and Experimental Design}

Forty male Holstein-Friesian calves were selected from 1 farm based on BW, age, and clinical health. Calves arrived at the research facilities in 3 batches and were equally divided over 5 blocks of 8 calves based on BW. Within each block, pairs of calves were assigned to 1 of $4 \mathrm{MR}$ treatments $(\mathrm{n}=10$ per treatment, $\mathrm{n}=2$ per treatment per block). Each block was separated by $1 \mathrm{wk}$, which was required because of the capacity of the respiration chambers. At the start of the experiment, weight and age of the calves (mean $\pm \mathrm{SE}$ ) were $114 \pm$ $2.4 \mathrm{~kg}$ and $97 \pm 1.4 \mathrm{~d}$, respectively.

After arrival, calves received the control MR for 11 d; thereafter, the adaptation period started and calves were assigned to 1 of $4 \mathrm{MR}$. The control treatment (CON) contained $46.2 \%$ lactose as the only source of carbohydrates. In the other MR treatments, $15.0 \%$ of 1 of 3 lactose replacers [glucose (GLUC), fructose (FRUC), or glycerol (GLYC)] was included in the MR at the expense of lactose. Calves were fed these MR for $48 \mathrm{~d}$ before the experimental period started in which measurements on energy and protein metabolism were performed. This long adaptation period was applied to determine the long-term effects of these lactose replacers on energy and protein metabolism.

\section{Housing}

During the first $42 \mathrm{~d}$ of the adaptation period, calves were housed in groups of 5 on wooden, slatted floors without bedding material. Per calf, $2.0 \mathrm{~m}^{2}$ was available. Each group received the same MR, but the MR 
was provided individually. Within one group, calves were assigned to multiple blocks. Lights were on from 0630 to $1730 \mathrm{~h}$. The stable was mechanically ventilated and the minimum and maximum temperature and humidity (mean $\pm \mathrm{SE}$ ) were $17.1 \pm 0.10$ and $19.7 \pm$ $0.13^{\circ} \mathrm{C}$ and $60 \pm 0.60$ and $77 \pm 0.50 \%$ during the entire experiment, respectively.

During the last $6 \mathrm{~d}$ of the adaptation period, calves were housed in metabolic cages $(0.8 \times 1.8 \mathrm{~m})$ and harnessed for habituation. During the experimental period, calves were housed in pairs in 1 of the 4 identical respiration chambers for $6.5 \mathrm{~d}$. Calves were housed in similar metabolic cages in the respiration chamber as during habituation. During housing in the chambers, audiovisual contact between calves was possible. Temperature and relative humidity were kept constant in the respiration chambers at $18^{\circ} \mathrm{C}$ and $65 \%$, respectively.

\section{Diets and Feeding}

Calves were fed individually according to their metabolic $\mathrm{BW}\left(\mathbf{B W}^{0.75}\right)$ at twice the ME requirement for maintenance. The ME requirement for maintenance was set at $460 \mathrm{~kJ} / \mathrm{kg}$ of $\mathrm{BW}^{0.75}$ per day (van Es et al., 1967). Milk replacer was provided in buckets and calves were locked in the headlock of the fence during MR feeding (maximum of $60 \mathrm{~min}$ ) to allow individual MR intake. The ingredient and nutrient composition of the experimental MR are shown in Table 1. The CON MR was composed of $85 \%$ basal MR and an additional 15\% lactose. For the GLUC, FRUC, and GLYC treatments, the $15 \%$ lactose was exchanged for glucose (Tereos Syral, Marckolsheim, France), fructose (Tate\&Lyle Europe, Boleraz, Slovakia), or glycerol (Triconor Distribution BV, Soest, the Netherlands) on a gross energy (GE) basis. The MR was mixed with water to obtain a concentration of $140 \mathrm{~g} / \mathrm{L}$. When the milk volume reached $9.0 \mathrm{~L}$, the concentration was increased to $160 \mathrm{~g} / \mathrm{L}$. Milk replacer was supplied to the calves at a temperature of approximately $42^{\circ} \mathrm{C}$ at 0630 and $1530 \mathrm{~h}$ in 2 equal portions. Milk replacer refusals were weighed and recorded after each feeding. Water was available ad libitum.

Solid feed supply equaled $10 \mathrm{~g}$ of $\mathrm{DM} / \mathrm{kg}$ of $\mathrm{BW}^{0.75}$ per day and was composed of $20 \%$ wheat straw and $80 \%$ concentrates on a DM basis. Concentrates were composed of $45.8 \%$ corn, $27.9 \%$ barley, $20.5 \%$ lupines, $3.4 \%$ premix, and $2.4 \%$ palm oil. Analyzed DM, CP, and GE content equaled $90.7 \%, 15.7 \%$ of DM, and 18.0 $\mathrm{kJ} / \mathrm{g}$ of $\mathrm{DM}$ for concentrates and $92.1 \%, 3.2 \%$ of DM, and $18.2 \mathrm{~kJ} / \mathrm{g}$ of $\mathrm{DM}$ for wheat straw, respectively. Solid feed was provided per pen (i.e., 5 calves) during group housing and per calf during individual housing in metabolic cages. Solid feed was provided in 2 portions per day, directly after MR feeding. Solid feed refusals were weighed and recorded once a day, before feeding MR in the morning.

\section{Measurements of Complete Energy and N Balance}

Calves were weighed weekly to adapt the feeding level to their $\mathrm{BW}^{0.75}$. In addition, calves were weighed before and after energy balance measurements. A complete energy and $\mathrm{N}$ balance was performed in the respiration chamber during $5 \mathrm{~d}$; the balance started after $0.5 \mathrm{~d}$. On d 6 in the respiration chamber, calves were subjected to an intravenous glucose tolerance test to measure insulin sensitivity [results are presented elsewhere; A. Pantophlet, M. Gilbert, J. van den Borne, W. Gerrits, H. Roelofsen (Medical Biomics, University Medical Centre Groningen, Groningen, the Netherlands), M.

Table 1. Ingredient and nutrient composition of the experimental milk replacer

\begin{tabular}{|c|c|}
\hline Item & Measurement \\
\hline \multicolumn{2}{|l|}{ Ingredient $(\%)$} \\
\hline Lactose or lactose replacer ${ }^{1}$ & 15.0 \\
\hline \multicolumn{2}{|l|}{ Basal diet } \\
\hline Whey protein concentrate & 39.1 \\
\hline Delactosed whey & 24.5 \\
\hline \multicolumn{2}{|l|}{ Fat } \\
\hline Lard & 7.2 \\
\hline Tallow & 7.2 \\
\hline Coconut oil & 3.9 \\
\hline Lecithin & 0.6 \\
\hline Emulsifier & 0.6 \\
\hline Calcium formate & 0.8 \\
\hline Premix $^{2}$ & 1.0 \\
\hline Methionine & 0.1 \\
\hline \multicolumn{2}{|c|}{ Nutrient ( $\%$ of DM, unless otherwise noted) } \\
\hline $\mathrm{DM}^{3} \%$ & 96.6 \\
\hline Crude ash & 7.4 \\
\hline $\mathrm{CP}, \mathrm{N} \times 6.25$ & 20.5 \\
\hline Crude fat & 20.9 \\
\hline Lactose $^{1,4}$ & 47.8 \\
\hline Lysine $^{4}$ & 1.6 \\
\hline Methionine $^{4}$ & 0.5 \\
\hline Threonine $^{4}$ & 1.3 \\
\hline Iron, $\mathrm{mg} / \mathrm{kg}$ of $\mathrm{DM}$ & 58.7 \\
\hline Gross energy, MJ/kg & 19.8 \\
\hline
\end{tabular}

${ }^{1}$ The control treatment contained $46.2 \%$ lactose as the only source of carbohydrates. In the other milk replacer treatments, $15.0 \%$ of 1 of 3 lactose replacers (i.e., glucose, fructose or glycerol) was included at the expense of lactose on a gross energy basis. Gross energy content equaled $15.14 \mathrm{~kJ} / \mathrm{g}$ of lactose, $13.96 \mathrm{~kJ} / \mathrm{g}$ of glucose, $15.38 \mathrm{~kJ} / \mathrm{g}$ of fructose, and $17.65 \mathrm{~kJ} / \mathrm{g}$ of glycerol.

${ }^{2}$ Provided (per kg of experimental diet): CP, $0.7 \mathrm{~g}$; starch, $5.0 \mathrm{~g}$; crude ash, $1.5 \mathrm{~g}$; Ca, $17 \mathrm{mg}$; P, $7.5 \mathrm{mg}$; Na, $0.7 \mathrm{mg}$; K, $7.3 \mathrm{mg}$; Cl, $13 \mathrm{mg}$; Mg, 0.5 g; Fe, 45 mg; Cu, 8.0 mg; Zn, 0.1 g; Mn, 43 mg; Se, 0.3 mg I, $1.0 \mathrm{mg}$; vitamin A, 25,013 IU; vitamin $\mathrm{D}_{3}, 4,002 \mathrm{IU}$; vitamin $\mathrm{E}, 150$ $\mathrm{IU}$; vitamin $\mathrm{K}_{3}, 2.1 \mathrm{mg}$; vitamin $\mathrm{C}, 0.3 \mathrm{~g}$; vitamin $\mathrm{B}_{1}, 8.2 \mathrm{mg}$; vitamin $\mathrm{B}_{2}, 10 \mathrm{mg}$; vitamin $\mathrm{B}_{3}, 35 \mathrm{mg}$; vitamin $\mathrm{B}_{5}, 18 \mathrm{mg}$; vitamin $\mathrm{B}_{6}, 10 \mathrm{mg}$; vitamin $\mathrm{B}_{12}, 0.1 \mathrm{mg}$; biotin, $0.2 \mathrm{mg}$; choline, $0.4 \mathrm{~g}$; folic acid, $0.7 \mathrm{mg}$. ${ }^{3}$ Dry matter content of the basal milk replacer.

${ }^{4}$ Calculated content. 
Priebe (Department of Pediatrics; Center for Liver, Digestive and Metabolic Diseases, University Medical Centre Groningen, Groningen, the Netherlands), and R. Vonk (Medical Biomics, University Medical Centre Groningen, Groningen, the Netherlands), unpublished data]; therefore, this day was not taken into account for the energy and $\mathrm{N}$ balance measurements. Gas exchange $\left(\mathrm{O}_{2}, \mathrm{CO}_{2}, \mathrm{CH}_{4}\right)$ was measured in 12-min intervals (Verstegen and Hoogerbrugge, 1987). Total feces were collected quantitatively per calf using plastic bags attached to the harnesses of the calves and were changed 2 or 3 times a day. Feces were stored at $-20^{\circ} \mathrm{C}$ pending further processing. Feces were pooled over 3 periods within the 5 -d balance period. Feces were pooled for the $48 \mathrm{~h}$ before isotope feeding (see below) for the determination of background ${ }^{13} \mathrm{C}$ enrichment, for the 48 $\mathrm{h}$ after isotope feeding for the determination of ${ }^{13} \mathrm{C}$ enrichment, and for the last $24 \mathrm{~h}$. For the determination of total-tract nutrient disappearance, parts of the feces of all 3 periods were pooled. Urine was collected quantitatively per calf using buckets under the metabolic cages containing $1,500 \mathrm{~mL}$ of sulfuric acid to prevent microbial activity and volatilization of $\mathrm{N}$ through $\mathrm{NH}_{3}$. Acidified urine was weighed and specific gravity was determined. Acidified urine was subsampled and stored at $-20^{\circ} \mathrm{C}$ until analyses. Outgoing air was subsampled and ammonia was captured in sulfuric acid, collected quantitatively, and sampled. Water that condensed on the heat exchanger was collected quantitatively and sampled. Milk replacer refusals were weighed, sampled, and stored at $-20^{\circ} \mathrm{C}$. Solid feed refusals were collected quantitatively and stored at $-20^{\circ} \mathrm{C}$. Basal $\mathrm{MR}$, lactose, glucose, fructose, glycerol, concentrates, and wheat straw were sampled weekly.

On the third day in the respiration chamber, GLUC, FRUC, and GLYC calves received $1.5 \mathrm{~g}$ of $\left[\mathrm{U}_{-}{ }^{13} \mathrm{C}\right]$ glucose (99 atom\%, Cambridge Isotope Laboratories), $\left[\mathrm{U}_{-}{ }^{13} \mathrm{C}\right]$ fructose $(99 \%$, Cambridge Isotope Laboratories), or $\left[\mathrm{U}_{-}{ }^{13} \mathrm{C}\right]$ glycerol (99 atom\%, Sigma Aldrich), respectively, with their morning MR meal. The $\left[\mathrm{U}_{-}{ }^{13} \mathrm{C}\right]$ fructose was not fed during the first block and 0.75 $\mathrm{g}$ of $\left[\mathrm{U}_{-}{ }^{13} \mathrm{C}\right]$ fructose (99 atom\%, Sigma Aldrich) was provided to the FRUC calves in the second block. The ${ }^{13} \mathrm{C}$ enrichment in expired $\mathrm{CO}_{2}$ was measured every 12 min using nondispersive infrared spectrometry (Alferink et al., 2003) to calculate oxidation of the ${ }^{13} \mathrm{C}$ enriched lactose replacers. Recovery of ${ }^{13} \mathrm{C}$ in feces was measured as an indicator of absorbance of these lactose replacers. When a lactose replacer was not absorbed from the intestinal lumen, it could either be excreted with the feces directly, or, more likely, be fermented by microbes. Both result in the excretion of ${ }^{13} \mathrm{C}$ in feces, the latter through the excretion of microbes that have incorporated ${ }^{13} \mathrm{C}$ of the lactose replacers into their own biomass. On the same day the isotopes were fed, the responses in blood glucose and insulin to MR feeding were measured by collecting 9 blood samples using central venous catheters (Careflow, Becton Dickinson, Alphen aan den Rijn, the Netherlands), which were inserted into the jugular vein before calves were moved to the respiration chambers [results are presented elsewhere; A. Pantophlet, M. Gilbert, J. van den Borne, W. Gerrits, H. Roelofsen (Medical Biomics, University Medical Centre Groningen, Groningen, the Netherlands), M. Priebe (Department of Pediatrics; Center for Liver, Digestive and Metabolic Diseases, University Medical Centre Groningen, Groningen, the Netherlands), and R. Vonk (Medical Biomics, University Medical Centre Groningen, Groningen, the Netherlands), unpublished data].

\section{Chemical Analyses of Feed and Energy and N Balance Samples}

Basal MR samples were pooled and analyzed for DM, $\mathrm{N}$, and GE content. Concentrates and wheat straw samples were pooled, ground to pass a $1-\mathrm{mm}$ screen, and analyzed for DM, N, and GE content. Solid feed refusals were pooled per calf, ground to pass a $1-\mathrm{mm}$ screen, and analyzed for DM, N, and GE content. Milk replacer refusals were thawed, homogenized, and analyzed for DM content after freeze drying, and the $\mathrm{N}$ and GE contents were assumed equal to the $\mathrm{N}$ and GE contents of the MR DM. Urine was thawed and analyzed for $\mathrm{N}$ and glucose content and freeze-dried before GE analysis. Feces were freeze-dried and ground to pass a 1-mm screen. Feces collected before isotope feeding were analyzed on ${ }^{13} \mathrm{C}$ enrichment. Feces collected after isotope feeding were analyzed for DM content, ${ }^{13} \mathrm{C}$ enrichment, and total $\mathrm{C}$ content. Feces collected over the total balance period were analyzed for DM and GE content. Last, $\mathrm{N}$ was analyzed in fresh feces, condensed water containing ammonium, and in sulfuric acid solution containing aerial ammonia.

Dry matter content was determined according to ISO standard 6496 (ISO, 1999b). Kjeldahl N and crude fat content were analyzed according to ISO standard 5983-2 (ISO, 2005) and ISO standard 6492 (ISO, 1999a), respectively. Gross energy content was analyzed with bomb calorimetry according to ISO standard 9831 (ISO, 1998). Crude ash content was analyzed according to ISO standard 5984 (ISO, 2002). Total C content and ${ }^{13} \mathrm{C}$ enrichment were analyzed after ball milling, using combustion isotope ratio mass spectrometry (Finnigan Delta V advantage isotope ratio mass spectrometer, Finnigan MAT, Bremen, Germany). Urinary glucose 
was analyzed with an enzymatic colorimetric method using the Roche/Hitachi Modular P800 automatic analyzer (Roche Diagnostics, Mannheim, Germany). Analyses were performed in duplicate, except urinary glucose, which was analyzed once.

\section{Calculations}

Apparent total-tract disappearance of DM, N, and energy were calculated as the difference between intake and excretion with the feces, expressed as a percentage of intake. Gross energy intake was calculated by subtracting the feed refusals from feed provided and multiplying by the GE content. Digestible energy (DE) intake was calculated by subtracting the energy excreted with feces from GE intake. Metabolizable energy intake was calculated by subtracting energy excreted with urine and $\mathrm{CH}_{4}$ from DE intake. Energy retention was calculated by subtracting heat production (calculated using the equation of Brouwer, 1965) from ME intake. The metabolizability of DE was calculated as $\mathrm{ME}: \mathrm{DE} \times 100$. The respiratory quotient $(\mathbf{R Q})$ was calculated as the ratio between $\mathrm{CO}_{2}$ production and $\mathrm{O}_{2}$ consumption. The diurnal fluctuation in RQ was calculated as the maximum minus the minimum RQ.

Nitrogen retention was calculated by subtracting $\mathrm{N}$ losses with feces, urine, condensed water, and sulfuric acid solution from $\mathrm{N}$ intake. Protein retention was calculated as $\mathrm{N}$ retention $\times 6.25$. Energy retained as fat was calculated by subtracting energy retained as protein (protein retention in $\mathrm{g} \times 23.7 \mathrm{~kJ} / \mathrm{g}$ ) from energy retention.

The ${ }^{13} \mathrm{CO}_{2}$ production from $\left[\mathrm{U}_{-}{ }^{13} \mathrm{C}\right]$ glucose, $\left[\mathrm{U}_{-}{ }^{13} \mathrm{C}\right]$ fructose, and $\left[\mathrm{U}_{-}{ }^{13} \mathrm{C}\right]$ glycerol was calculated by multiplying $\mathrm{CO}_{2}$ production with ${ }^{13} \mathrm{C}$ enrichment in expired $\mathrm{CO}_{2}$ and corrected for background enrichment. The area under the curve was integrated for calculating ${ }^{13} \mathrm{CO}_{2}$ production over a period for $30 \mathrm{~h}$ after isotope feeding. Oxidation of $\left[\mathrm{U}_{-}{ }^{13} \mathrm{C}\right]$ glucose, $\left[\mathrm{U}_{-}{ }^{13} \mathrm{C}\right]$ fructose, and $\left[\mathrm{U}_{-}{ }^{13} \mathrm{C}\right]$ glycerol was expressed as a percentage of the dose provided, after correction for the number of C-atoms, chemical purity, and isotopic enrichment. Oxidation was corrected for an incomplete bicarbonate recovery of $72 \%$, which was observed in milk-fed calves by van den Borne et al. (2007). For the pattern of ${ }^{13} \mathrm{CO}_{2}$ production in time, ${ }^{13} \mathrm{CO}_{2}$ production was averaged per hour and expressed as a percentage of the dose provided.

The excretion of ${ }^{13} \mathrm{C}$ in feces was calculated. Total $\mathrm{C}$ output with the feces after isotope feeding $(\mathrm{g} / 48 \mathrm{~h})$ was calculated by multiplying the amount of feces produced ( $\mathrm{g}$ of $\mathrm{DM} / 48 \mathrm{~h}$ ) with the carbon content. Total $\mathrm{C}$ output in moles per $48 \mathrm{~h}$ was calculated by multiply- ing total $\mathrm{C}$ output ( $\mathrm{g}$ of DM per $48 \mathrm{~h}$ ) with the mean molecular weight of carbon in the feces after isotope feeding, which was calculated from the ${ }^{13} \mathrm{C}$ enrichment of the feces. Finally, ${ }^{13} \mathrm{C}$ excretion with feces after isotope feeding was calculated by multiplying the total $\mathrm{C}$ output $(\mathrm{mol} / 48 \mathrm{~h})$ with the atom percentage excess (i.e., the atom percentage of feces after isotope feeding corrected for background enrichment). Recovery of ${ }^{13} \mathrm{C}$ isotopes in feces was expressed as a percentage of the dose provided after correction for the number of Catoms, chemical purity, and isotopic enrichment.

\section{Statistical Analyses}

All statistical analyses were performed with SAS 9.3 (SAS Institute Inc., Cary, NC). Studentized residuals of all models were checked for homogeneity of variance based on the Shapiro-Wilk test. Observations were classified as outliers when the studentized residual was greater than 3 or lower than -3. Apparent totaltract disappearance, fecal $\mathrm{pH}$ and $\mathrm{DM}$ content, ADG, urinary glucose excretion, and $\mathrm{N}$ and energy balance traits were analyzed for treatment and block effects by ANOVA using the GLM procedure. Pairs of calves (housed in one respiration chamber) were considered as the experimental unit for the $\mathrm{N}$ and energy balance traits and the individual calf was the experimental unit for the other variables. The CORR procedure was used to estimate the Pearson correlation coefficients.

Circadian patterns of RQ and heat production were averaged per hour and analyzed on treatment, time, treatment $\times$ time interaction, and block effects using the GLIMMIX procedure. Time was included as a random statement with calf as subject. Based on fit statistics (AIC and BIC), the Toeplitz covariance structure was used. The Kenward-Roger method was used for computing the denominator degrees of freedom (Kenward and Roger, 1997). The diurnal fluctuation in RQ and the 24-h RQ were analyzed for treatment effects by ANOVA using the GLM procedure. One outlier was identified for the diurnal fluctuation in RQ, which was a calf housed individually in the respiration chamber in block 3. This observation was deleted for the analysis on the diurnal fluctuation in RQ.

Excretion of ${ }^{13} \mathrm{C}$ in feces (experimental unit is calf) and as ${ }^{13} \mathrm{CO}_{2}$ in expired breath (experimental unit is pair of calves) were analyzed on treatment and block effects by ANOVA using the GLM procedure. Recovery of ${ }^{13} \mathrm{C}$ in the feces was square root-transformed to obtain homogeneity of variance.

Differences were considered significant when $P<$ 0.05 and considered a trend when $0.05<P<0.10$. When main effects were significant, pairwise compari- 
Table 2. Apparent total-tract disappearance of DM, energy, and nitrogen in calves fed a milk replacer containing $46.2 \%$ lactose $(\mathrm{CON} ; \mathrm{n}=10)$ or $15.0 \%$ glucose (GLUC; $\mathrm{n}=8$ ), fructose (FRUC; $\mathrm{n}=9$ ), or glycerol (GLYC; $\mathrm{n}=10$ ) included at the expense of lactose on gross energy basis and recovery of ${ }^{13} \mathrm{C}$ in feces after feeding a single dose of ${ }^{13} \mathrm{C}$-labeled glucose, fructose or glycerol

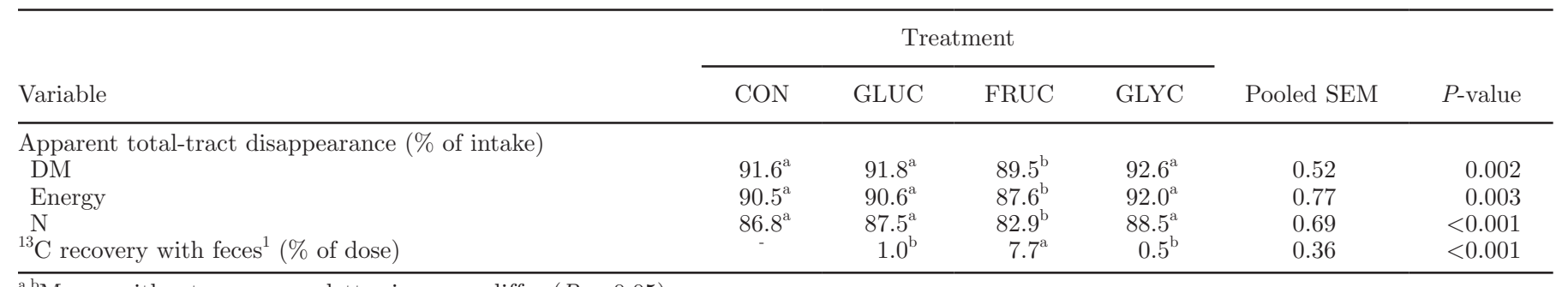

${ }_{\mathrm{a}, \mathrm{b}}$ Means without a common letter in a row differ $(P<0.05)$.

${ }^{1} \mathrm{n}=8$ for FRUC.

sons were made using the Tukey method. Results are expressed as nontransformed means and their pooled standard error of the mean.

\section{RESULTS}

Average daily gain in the adaptation period did not differ between treatments and averaged 1,292 $\pm 40.5 \mathrm{~g}$. One GLUC calf did not enter the respiration chamber due to ruminal drinking (i.e., MR leaking into the rumen due to malfunction of the esophageal groove reflex) resulting in bloat. Another GLUC calf was, therefore, housed individually in a respiration chamber. This calf was allowed to have visual contact with calves in the adjacent respiration chamber to minimize stress. This individually housed calf did not have any feed refusals. Two experimental units (FRUC in block 1 and GLUC in block 5) were excluded from statistical analyses due to development of diarrhea and incomplete feces collection in a FRUC calf, and development of a high body temperature $\left(>40^{\circ} \mathrm{C}\right.$ for $\left.2 \mathrm{~d}\right)$ in a GLUC calf. For measurements where calf was the experimental unit (i.e., apparent total-tract disappearance and fecal ${ }^{13} \mathrm{C}$ excretion), only these individual calves were excluded from statistical analyses.

\section{Digestibility}

In 4 calves (2 GLUC and 2 FRUC calves), part of the feces had leaked from the fecal bags and was collected from the funnel underneath the metabolic cage. These feces were collected and analyzed and added to fecal excretion. Feces production of FRUC calves $(309 \pm 22.4 \mathrm{~g}$ of $\mathrm{DM} / \mathrm{d})$ was greater compared with the other treatments $(232 \pm 12.6 \mathrm{~g}$ of $\mathrm{DM} / \mathrm{d}$, on average; $P=0.002)$. This resulted in a decreased apparent total-tract disappearance of $\mathrm{DM}(P=0.002)$ and energy $(P=0.003)$ for the FRUC treatment compared with the other treatments (Table 2). Apparent total- tract $\mathrm{N}$ disappearance was also decreased for FRUC calves $(P<0.001)$. Fecal pH was lower $(P<0.001)$ for FRUC calves $(6.1 \pm 0.12)$ than for other calves $(7.2 \pm$ $0.14)$. Fecal DM content was affected by treatment $(P$ $=0.029)$ and was lowest for FRUC calves $(133 \pm 7.4$ $\mathrm{g} / \mathrm{kg})$ and highest for GLYC calves $(167 \pm 6.9 \mathrm{~g} / \mathrm{kg})$, with intermediate values for CON $(149 \pm 5.6 \mathrm{~g} / \mathrm{kg})$ and GLUC calves $(153 \pm 9.1 \mathrm{~g} / \mathrm{kg})$.

\section{Energy and N Balance}

The effects of dietary treatments on energy and N balances are shown in Table 3. Energy retention did not differ between treatments and averaged $299 \pm 16 \mathrm{~kJ} / \mathrm{kg}$ of $\mathrm{BW}^{0.75}$ per day. Urinary energy losses were greater $(P=0.034)$ for GLUC calves than for FRUC calves. Urinary glucose excretion was affected by treatment $(P$ $<0.001$ ), with greater urinary glucose losses for CON $\left(8.3 \pm 1.11 \mathrm{~kJ} / \mathrm{kg}\right.$ of $\mathrm{BW}^{0.75}$ per day) and GLUC $(13.2$ $\pm 3.71 \mathrm{~kJ} / \mathrm{kg}$ of $\mathrm{BW}^{0.75}$ per day) calves than for FRUC $\left(1.3 \pm 0.34 \mathrm{~kJ} / \mathrm{kg}\right.$ of $\mathrm{BW}^{0.75}$ per day) and GLYC calves $\left(1.9 \pm 0.52 \mathrm{~kJ} / \mathrm{kg}\right.$ of $\mathrm{BW}^{0.75}$ per day). Methane production was greatest for GLYC calves $(P=0.008)$ and equaled $8.7 \pm 0.37 \%$ when expressed as percentage of GE intake from solid feed, but only accounted for $1.7 \%$ of total energy losses. Methane production was not related to solid feed refusals $(\mathrm{r}=-0.15, P=0.55)$. A trend for metabolizability of DE $(P=0.05)$ was noted, which was caused by a greater metabolizability of $\mathrm{DE}$ for FRUC calves (95.2 $\pm 0.09 \%)$ than for GLUC calves $(93.4 \pm 0.99 \%)$. The efficiency by which ME was retained did not differ between treatments and averaged $30 \pm 1.4 \%$.

Nitrogen retention $\left(0.79 \pm 0.04 \mathrm{~g}\right.$ of $\mathrm{N} / \mathrm{kg}$ of $\mathrm{BW}^{0.75}$ per day) and the efficiency by which digested $\mathrm{N}$ was retained $(52 \pm 2.5 \%)$ did not differ between treatments. However, fecal $\mathrm{N}$ losses were higher $(P<0.001)$ for FRUC calves $\left(0.30 \pm 0.01 \mathrm{~g}\right.$ of $\mathrm{N} / \mathrm{kg}$ of $\mathrm{BW}^{0.75}$ per day) than for other calves $\left(0.22 \pm 0.01 \mathrm{~g}\right.$ of $\mathrm{N} / \mathrm{kg}$ of $\mathrm{BW}^{0.75}$ 
Table 3. Nitrogen and energy balances in calves fed a milk replacer containing $46.2 \%$ lactose (CON) or $15.0 \%$ glucose (GLUC), fructose (FRUC), or glycerol (GLYC) included at the expense of lactose on gross energy basis

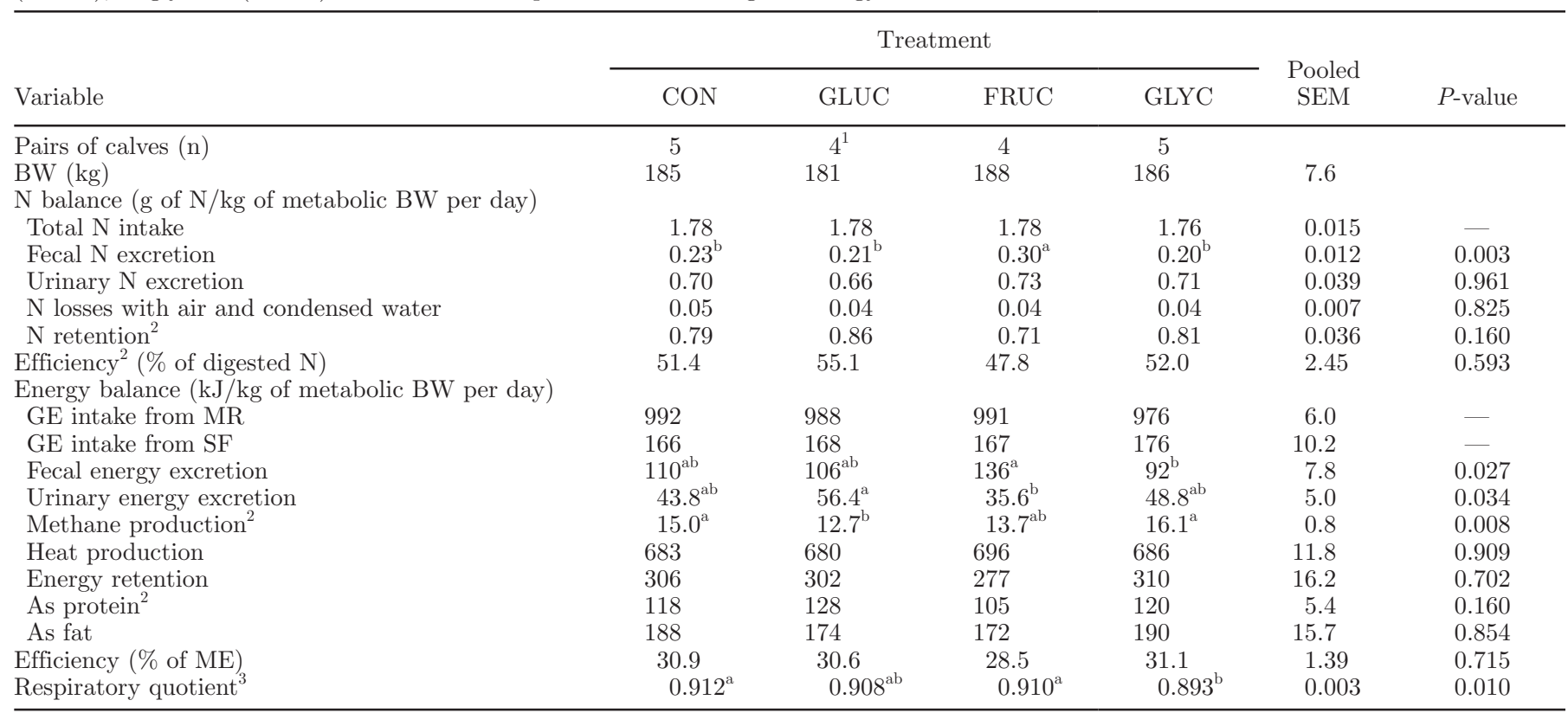

${ }^{\mathrm{a}, \mathrm{b}}$ Means without a common letter in a row differ $(P<0.05)$.

${ }^{1}$ In block 3, only 1 calf was housed in the respiration chamber.

${ }^{2} \mathrm{~N}$ retention $(P=0.044), \mathrm{N}$ retention efficiency $(P=0.046)$, methane production $(P=0.014)$, and energy retention as protein $(P=0.044)$ were affected by block.

${ }^{3}$ There was a trend for a lower respiratory quotient for GLYC compared with GLUC $(P=0.085)$.

per day). Nitrogen retention $(P=0.044)$ and the efficiency by which digested $\mathrm{N}$ was retained $(P=0.046)$ decreased with blocks later in time.

Circadian patterns of heat production and RQ are shown in Figures 1 and 2, respectively. Both patterns followed the ingestion of meals (time effect $P<0.001$ for both). A treatment $\times$ time interaction $(P=0.002)$ was found for RQ. In general, the RQ for GLYC calves was lower than for other calves at 2 to $6 \mathrm{~h}$ after feeding. During the night, the RQ was lower for GLUC calves than for CON calves at $13(P=0.08)$ and $15 \mathrm{~h}(P=$ $0.018)$ after the afternoon feeding. The diurnal fluctuation in RQ was affected by treatment $(P=0.032)$, with a greater diurnal fluctuation for GLUC calves $(0.14 \pm$ $0.014)$ compared with GLYC calves $(0.12 \pm 0.006)$, and intermediate values for CON $(0.12 \pm 0.009)$ and FRUC $(0.13 \pm 0.007)$ calves. The 24 -h RQ was lower $(P=$ $0.010)$ for GLYC calves $(0.89 \pm 0.001)$ than for other calves $(0.91 \pm 0.004)$. A treatment $\times$ time interaction was not found for heat production.

\section{Isotope Recovery}

Recovery of ${ }^{13} \mathrm{C}$ in feces and as ${ }^{13} \mathrm{CO}_{2}$ in expired breath after feeding $\left[\mathrm{U}_{-}{ }^{13} \mathrm{C}\right]$ glucose, $\left[\mathrm{U}_{-}{ }^{13} \mathrm{C}\right]$ fructose, or $\left[\mathrm{U}_{-}{ }^{13} \mathrm{C}\right]$ glycerol are presented in Table 2 and Figure 3.
Recovery of isotopes with feces was greater $(P<0.001)$ for FRUC calves than for GLUC and GLYC calves. Recovery of isotopes as ${ }^{13} \mathrm{CO}_{2}$ did not differ between treatments $(P=0.100)$ and averaged $72 \pm 1.6 \%$. The time at which the maximum rate of ${ }^{13} \mathrm{CO}_{2}$ production was reached $\left(\mathrm{T}_{\max }\right)$ was more than $3 \mathrm{~h}$ delayed $(P=$ 0.008 ) for FRUC calves $\left(\mathrm{T}_{\max }=515 \pm 39\right.$ min after feeding) compared with GLUC and GLYC calves ( $\mathrm{T}_{\max }$ $=294 \pm 30 \mathrm{~min}$ after feeding on average; Figure 3).

\section{DISCUSSION}

The objective of our study was to determine the effects of replacing lactose with glucose, fructose, or glycerol on energy and protein metabolism in veal calves. Apparent total-tract DM, N, and energy disappearance of the calves in our study were lower compared with those of calves fed exclusively MR (van den Borne et al., 2006b; Labussière et al., 2009), which can be ascribed to the lower apparent total-tract disappearance of the solid feed (Berends et al., 2012). The FRUC calves consistently had a lower apparent total-tract disappearance of DM, energy, and $\mathrm{N}$ than other calves. The increased fecal $\mathrm{N}$ losses in FRUC calves could result from increased $\mathrm{N}$ losses at the end of the ileum, as a result of a higher passage rate resulting in increased 


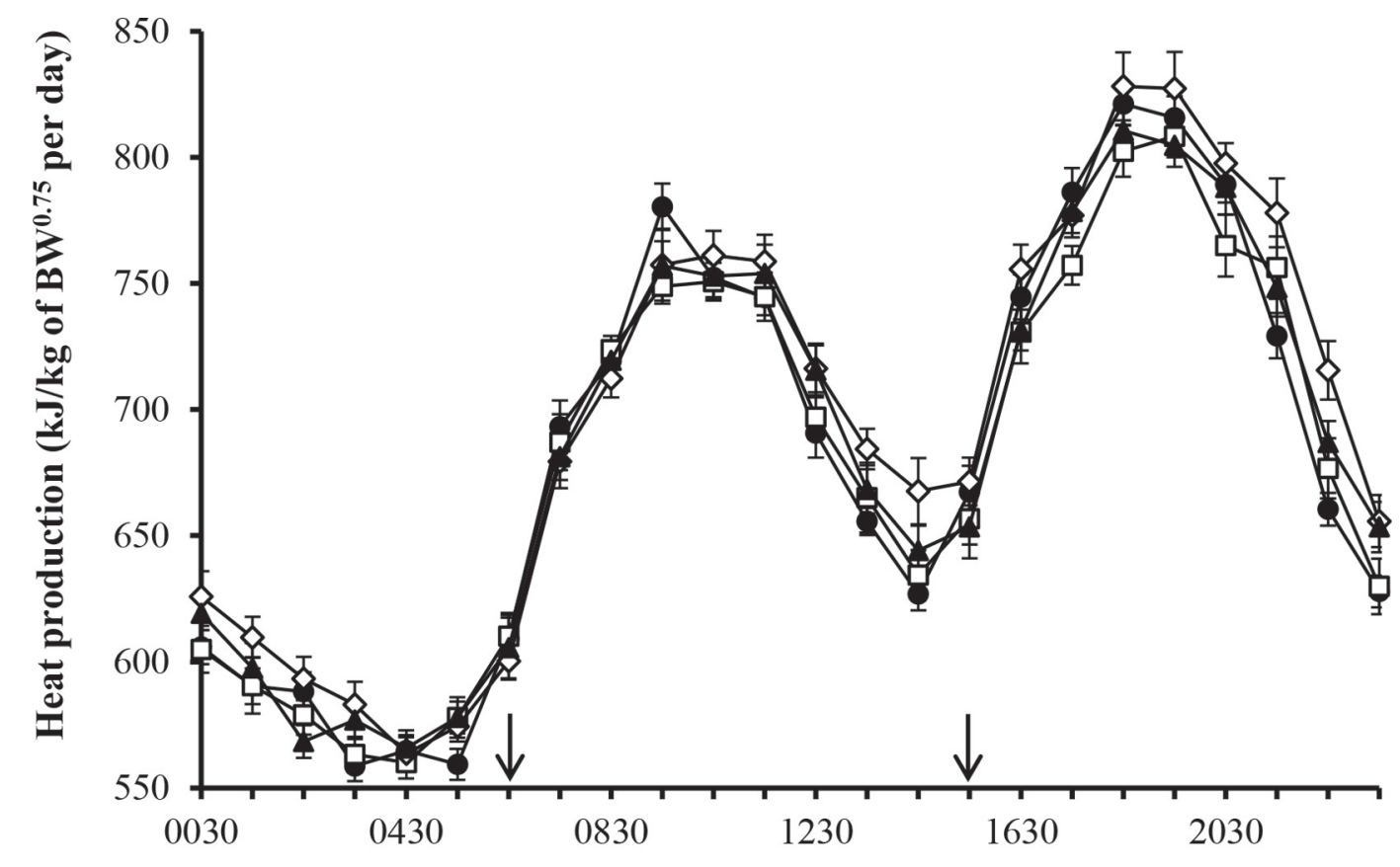

Time of day

Figure 1. Circadian pattern of heat production of calves fed a milk replacer containing $46.2 \%$ lactose (control; •) or $15.0 \%$ glucose $(\square)$, fructose $(\diamond)$, or glycerol $(\mathbf{\Lambda})$ included at the expense of lactose on gross energy basis. Arrows indicate feeding times. No treatment $\times$ time interaction was found $(P=0.821)$. Results are means and their SEM.

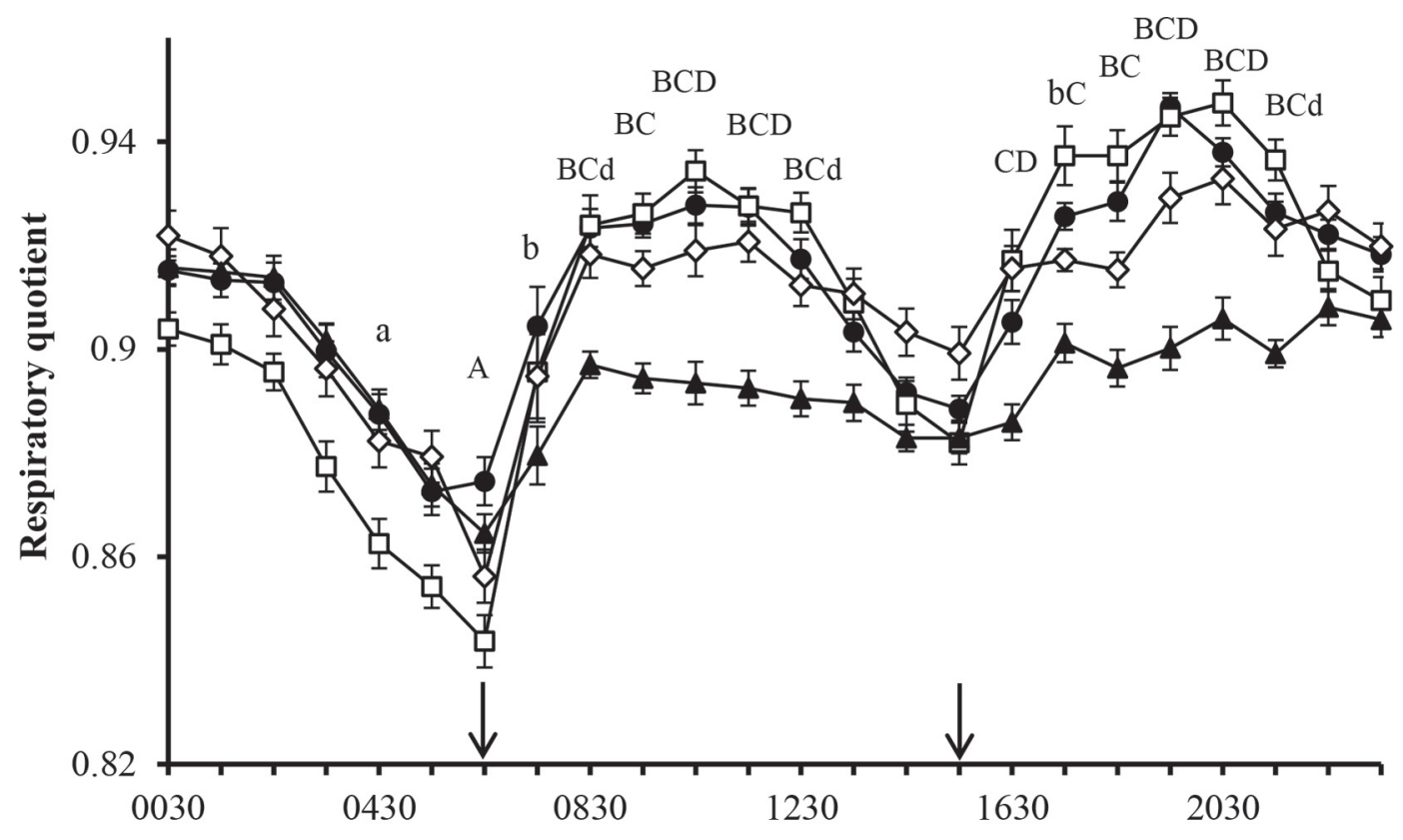

Time of day

Figure 2. Circadian pattern of the respiratory quotient of calves fed a milk replacer containing $46.2 \%$ lactose (control; $\bullet$ ) or $15.0 \%$ glucose $(\square)$, fructose $(\diamond)$, or glycerol $(\mathbf{\Lambda})$ included at the expense of lactose on gross energy basis. Arrows indicate feeding times. A treatment $\times$ time interaction $(P=0.002)$ was found. $\mathrm{A}=$ control differs from glucose; $\mathrm{B}=$ control differs from glycerol; $\mathrm{C}=$ glucose differs from glycerol; $\mathrm{D}=$ fructose differs from glycerol $(P<0.05) ; \mathrm{a}=$ control differs from glucose; $\mathrm{b}=$ control differs from glycerol; $\mathrm{d}=$ fructose differs from glycerol $(P$ $<0.10)$. Results are means and their SEM. 


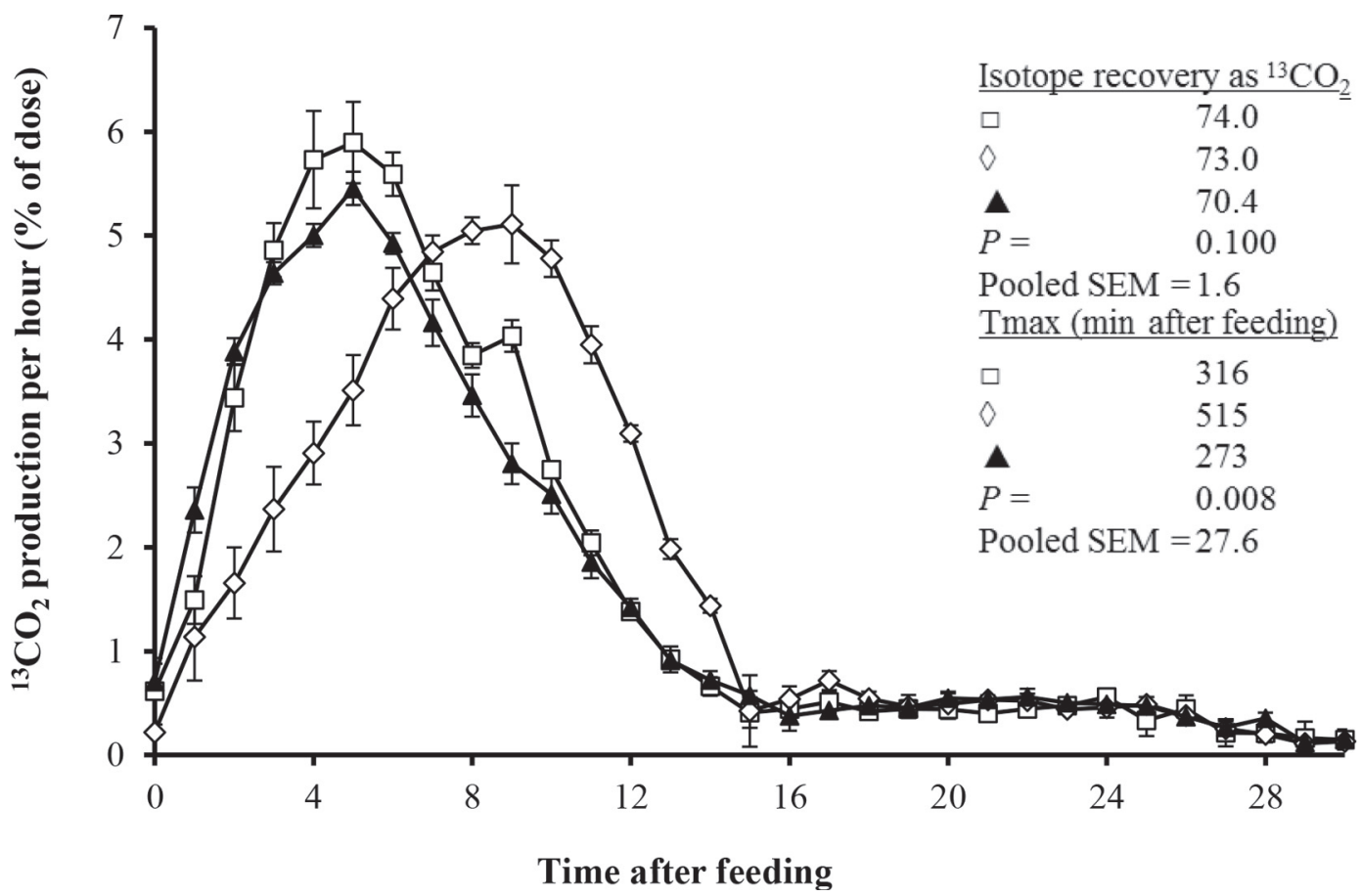

Figure 3. Production of ${ }^{13} \mathrm{CO}_{2}$, isotope recovery as ${ }^{13} \mathrm{CO}_{2}$ and time of maximum rate of production of ${ }^{13} \mathrm{CO}_{2}\left(\mathrm{~T}_{\max }\right)$ after feeding a single dose of ${ }^{13} \mathrm{C}$-labeled glucose $(\square)$, fructose $(\diamond)$, or glycerol $(\boldsymbol{\Lambda})$ to calves with the milk replacer containing isoenergetic amounts of glucose, fructose, or glycerol. Results are means and their SEM.

dietary or endogenous $\mathrm{N}$ losses. Alternatively, the increased fecal $\mathrm{N}$ losses could result from increased $\mathrm{N}$ losses in the large intestine, as a result of an influx of urea into the large intestine, which is used for microbial protein synthesis. The FRUC calves also had the greatest fecal ${ }^{13} \mathrm{C}$ excretion (i.e., $7.7 \pm 0.59 \%$ ). This fecal ${ }^{13} \mathrm{C}$ originates from the ${ }^{13} \mathrm{C}$-labeled fructose, but the form in which this ${ }^{13} \mathrm{C}$ is excreted is unknown. The ${ }^{13} \mathrm{C}$ could be excreted as fructose with the feces, although this seems unlikely, because microbes in the large intestine can ferment fructose. Fermentation of fructose, resulting in microbial biomass and VFA, could result in this increase in fecal ${ }^{13} \mathrm{C}$ excretion. This is supported by the low fecal $\mathrm{pH}$ and increased fecal $\mathrm{N}$ losses for FRUC calves. Assuming that all ${ }^{13} \mathrm{C}$ is excreted as microbial biomass and that only $20 \%$ of the fermented carbohydrate is excreted as microbial biomass with the feces [derived from $0.3 \mathrm{~kJ}$ of fecal biomass $/ \mathrm{kJ}$ ofcarbohydrate (Livesey, 1991) and using $15.56 \mathrm{~kJ} / \mathrm{g}$ of carbohydrate (Blaxter, 1989) and $23.13 \mathrm{~kJ} / \mathrm{g}$ of biomass (Cordier et al., 1987)], then $38.5 \%$ of the ${ }^{13} \mathrm{C}$-labeled fructose was fermented. The true disappearance of fructose, therefore, ranged between 61.5 and $92.3 \%$. Either way, it indicates that ileal disappearance of fructose is lower than that of glucose and glycerol, which could result in osmotic or fermentative diarrhea. Diarrhea has been reported after feeding a fructose solution to milk-fed calves (Velu et al., 1960; Siddons et al., 1969).

Despite the reduced fructose absorption, energy retention did not differ between the dietary treatments. Energy retention averaged $299 \pm 16 \mathrm{~kJ} / \mathrm{kg}$ of $\mathrm{BW}^{0.75}$ per day, which is in a similar range as in a study by Berends et al. (2012), who found an energy retention of $295 \mathrm{~kJ} /$ $\mathrm{kg}$ of $\mathrm{BW}^{0.75}$ per day for milk-fed calves weighing 164 $\mathrm{kg}$ of BW fed $9 \mathrm{~g}$ of $\mathrm{DM}$ of solid feed $/ \mathrm{kg}$ of $\mathrm{BW}^{0.75}$ per day and an MR with a GE content of $21.7 \mathrm{MJ} / \mathrm{kg}$ of DM. Energy losses with urine were greatest for GLUC calves, which was caused by greater urinary glucose excretion for GLUC calves. Urinary glucose excretion has been shown in milk-fed calves, and increased with age and feeding level (Vicari et al., 2008a; Labussière et al., 2009), with protein-free energy intake (Gerrits et al., 2008), and with nutrient asynchrony (Vicari et al., 2008b). To assess whether glycerol is excreted with urine as well, the urinary energy excretion not explained by glucose (assuming $15.56 \mathrm{~kJ} / \mathrm{g}$ glucose; Blaxter, 1989) and urea $\mathrm{N}$ (assuming $22.6 \mathrm{~kJ} / \mathrm{g}$ urea $\mathrm{N}$; Baldwin, 1995) was calculated. This unexplained urinary energy excretion was greater $(P=0.009)$ for GLYC calves $\left(30.8 \pm 1.01 \mathrm{~kJ} / \mathrm{kg}\right.$ of $\mathrm{BW}^{0.75}$ per day) than for other calves $\left(20.5 \pm 3.40 \mathrm{~kJ} / \mathrm{kg}\right.$ of $\mathrm{BW}^{0.75}$ per day), indicating that these calves excreted glycerol 
with the urine. Energy retention was not decreased for GLYC calves, which is in agreement with studies where no effect on growth performance was observed when replacing dietary corn with glycerol for growing-finishing pigs (Duttlinger et al., 2012) or when replacing 37.5\% of the lactose with glycerol in the MR for calves from 3 to $35 \mathrm{~d}$ of age (Ebert et al., 2008).

Nitrogen retention did not differ between treatments when using a pair of calves as experimental unit (Table 3 ). Feed intake and fecal and urinary $\mathrm{N}$ losses were measured individually and $\mathrm{N}$ retention was lower $(P$ $=0.027)$ in FRUC calves than in GLUC calves when calf was used as the experimental unit. This decreased $\mathrm{N}$ retention for FRUC calves was mainly caused by increased fecal $\mathrm{N}$ losses. Nitrogen retention and the efficiency by which digested $\mathrm{N}$ was retained decreased with blocks later in time, which is in agreement with the review of van den Borne (2006a) and with Labussière et al. (2009), who reported a decrease in $\mathrm{N}$ retention efficiency as calves got older and heavier.

Circadian patterns of RQ and heat production followed the ingestion of meals. The 24-h RQ of GLYC calves was lower than for other calves due to the lower RQ for the complete oxidation of glycerol (0.857; Elia and Cummings, 2007). The RQ of GLUC calves was lower when approaching the morning meal, which was also reflected in the greater diurnal fluctuation in GLUC calves. This indicates that lipid oxidation was greater for GLUC calves during the night as a response to low carbohydrate availability for oxidation. This is probably related to the greater amount of time that the renal threshold for glucose $(8.3 \mathrm{mmol} / \mathrm{L}$; HostettlerAllen et al., 1994; Vicari et al., 2008a) is exceeded in jugular blood in the GLUC calves after feeding [A. Pantophlet, M. Gilbert, J. van den Borne, W. Gerrits, H. Roelofsen (Medical Biomics, University Medical Centre Groningen, Groningen, the Netherlands), M. Priebe (Department of Pediatrics; Center for Liver, Digestive and Metabolic Diseases, University Medical Centre Groningen, Groningen, the Netherlands), and R. Vonk (Medical Biomics, University Medical Centre Groningen, Groningen, the Netherlands), unpublished data], resulting in greater excretion of urinary glucose after feeding and, therefore, less glucose is available for oxidation during the night. Indeed, urinary glucose excretion and the RQ during the night (i.e., the average $\mathrm{RQ}$ of the last $6 \mathrm{~h}$ before morning feeding) were negatively related $(\mathrm{r}=-0.50, P=0.033)$, and this relation was mainly caused by a high relation in the GLUC calves $(\mathrm{r}=-0.90, P<0.10)$.

Before the $1530 \mathrm{~h}$ feeding, the RQ of FRUC calves appeared to be greater than that of other calves, although only numerically. Most likely, fructose is con- verted to other metabolites before being oxidized. This is in agreement with the delay in ${ }^{13} \mathrm{CO}_{2}$ production after feeding ${ }^{13} \mathrm{C}$-labeled fructose compared with glucose and glycerol. Fructose could be converted into glucose (calves; Siddons et al., 1969; Kurz and Willett, 1992), lactate (humans and rats; Pereira and Jangaard, 1971; Swanson et al., 1992; Chong et al., 2007; Teff et al., 2009), and glycogen (rats; Pereira and Jangaard, 1971). In humans, $50 \%$ of the fructose, which is metabolized by the liver, is converted into glucose, $25 \%$ into lactate, 15 to $18 \%$ into glycogen, and 1 to $5 \%$ into free fatty acids (as reviewed by Rippe and Angelopoulos, 2013). This indicates that only 2 to $9 \%$ of the fructose is oxidized directly, which is in agreement with the delay in ${ }^{13} \mathrm{CO}_{2}$ production that we found after feeding. The conversion of fructose into VFA before oxidation is possible as well in our study. Despite the delay in the maximum rate of ${ }^{13} \mathrm{CO}_{2}$ for FRUC, the recovery of the isotopes as ${ }^{13} \mathrm{CO}_{2}$ was equal between lactose replacers and averaged $72 \%$. This is slightly lower than recovery of ${ }^{13} \mathrm{CO}_{2}$ after feeding ${ }^{13} \mathrm{C}$-labeled glucose in a previous study with heavy milk-fed calves ( $80 \%$ on average; van den Borne et al., 2007). The recovery of isotopes as ${ }^{13} \mathrm{CO}_{2}$ expressed as a percentage of the amount of ${ }^{13} \mathrm{C}$ not excreted with feces results in a recovery of $74.8 \pm 2.36,79.1 \pm 1.31$, and $70.8 \pm 0.91 \%$ for GLUC, FRUC, and GLYC calves, respectively. This suggests that oxidation of digested FRUC is greater than that of digested GLYC and GLUC $(P=0.005)$. This corresponds with the urinary energy losses, which are lowest for FRUC calves, and is in agreement with humans, where ingested fructose is oxidized to a greater extent than ingested glucose (Tappy et al., 1986). The amount of isotopes not lost with feces or breath was greatest for GLYC calves $(P$ $=0.002)$ and equaled $29.0 \pm 0.90,24.9 \pm 2.31$, and $19.3 \pm 1.25 \%$ for GLYC, GLUC, and FRUC calves, respectively. This is in agreement with our results on energy retention (GLYC > GLUC > FRUC).

In conclusion, in contrast to our hypothesis, energy and $\mathrm{N}$ retention were not affected when replacing $>30 \%$ of the lactose from the calf milk replacer with glucose, fructose, or glycerol. Apparent total-tract disappearance of DM, energy, and N of GLUC and GLYC calves were comparable with CON calves, but fecal losses of DM, energy, and N were increased for FRUC calves. In agreement with our hypothesis, postabsorptive losses occurred with the urine for glucose, which caused a lower RQ for GLUC calves during the night. Postabsorptive losses also occurred with the urine for glycerol. Furthermore, fructose was oxidized more slowly than glucose and glycerol, probably as a result of conversion into other substrates, such as glucose or lactate, before oxidation. 


\section{ACKNOWLEDGMENTS}

The authors thank Rik van Erp, Tamme Zandstra, Sven Alferink, Marcel Heetkamp, Joswita van der Velde, and the personnel of the Carus experimental facilities of Wageningen University for their skilled technical assistance. This project was jointly financed by the European Union, European Regional Development Fund and The Ministry of Economic Affairs, Agriculture and Innovation, Peaks in the Delta, the Municipality of Groningen, the Provinces of Groningen, Fryslân and Drenthe as well as the Dutch Carbohydrate Competence Center (CCC2 WP21). Financial support was also provided by Tereos Syral (Marckolsheim, France), VanDrie Group (Mijdrecht, the Netherlands), andWageningen University.

\section{REFERENCES}

Alferink, S. J. J., J. J. G. C. van den Borne, W. J. J. Gerrits, S. C. W. Lammers-Wienhoven, and M. J. W. Heetkamp. 2003. On-line, continuous determination of ${ }^{13} \mathrm{CO} 2 /{ }^{12} \mathrm{CO} 2$ ratios by non-dispersive infrared absorption in indirect calorimetry facilities. Pages 465-468 in Proc. Progress in Research on Energy and Protein Metabolism, Rostock-Warnemünde, Germany. W. B. Souffrant and C. C. Metges, ed. Wageningen Academic Publishers, Wageningen, the Netherlands.

Baldwin, R. L. 1995. Modeling Ruminant Digestion and Metabolism. Chapman \& Hall, London, UK.

Berends, H., J. J. G. C. van den Borne, S. J. J. Alferink, C. G. van Reenen, E. A. M. Bokkers, and W. J. J. Gerrits. 2012. Low-protein solid feed improves the utilization of milk replacer for protein gain in veal calves. J. Dairy Sci. 95:6654-6664.

Blaxter, K. L. 1989. Energy Metabolism in Animals and Man. Cambridge University Press, Cambridge, UK.

Brouwer, E. 1965. Report of sub-committee on constants and factors. Pages 441-443 in Energy Metabolism. K. L. Blaxter, ed. Academic Press, London, UK.

Burant, C. F., J. Takeda, E. Brot-Laroche, G. I. Bell, and N. O. Davidson. 1992. Fructose transporter in human spermatozoa and small intestine is GLUT5. J. Biol. Chem. 267:14523-14526.

Chong, M. F. F., B. A. Fielding, and K. N. Frayn. 2007. Mechanisms for the acute effect of fructose on postprandial lipemia. Am. J. Clin. Nutr. 85:1511-1520.

Coombe, N. B., and R. H. Smith. 1973. Absorption of glucose and galactose and digestion and absorption of lactose by the preruminant calf. Br. J. Nutr. 30:331-344.

Coombe, N. B., and R. H. Smith. 1974. Digestion and absorption of starch, maltose and lactose by the preruminant calf. Br. J. Nutr. $31: 227-235$.

Cordier, J. L., B. M. Butsch, B. Birou, and U. Von Stockar. 1987. The relationship between elemental composition and heat of combustion of microbial biomass. Appl. Microbiol. Biotechnol. 25:305-312.

Curry, D. L. 1989. Effects of mannose and fructose on the synthesis and secretion of insulin. Pancreas 4:2-9.

Duttlinger, A. J., J. M. DeRouchey, M. D. Tokach, S. S. Dritz, R. D. Goodband, J. L. Nelssen, T. A. Houser, and R. C. Sulabo. 2012. Effects of increasing crude glycerol and dried distillers grains with solubles on growth performance, carcass characteristics, and carcass fat quality of finishing pigs. J. Anim. Sci. 90:840-852.

Ebert, R. A., G. M. Willis, and J. K. Drackley. 2008. Efficacy of glycerol as a replacement for lactose in calf milk replacer. J. Anim. Sci. 86:68 (Abstr.)

Elia, M., and J. H. Cummings. 2007. Physiological aspects of energy metabolism and gastrointestinal effects of carbohydrates. Eur. J. Clin. Nutr. 61:S40-S74.
Gerrits, W. J. J., J. J. G. C. van den Borne, and J. W. Blum. 2008. Low-dietary protein intake induces problems with glucose homeostasis and results in hepatic steatosis in heavy milk-fed calves. Domest. Anim. Endocrinol. 35:121-129.

Gilbert, M. S., A. J. Pantophlet, H. Berends, A. M. Pluschke, J. J. G. C. van den Borne, W. H. Hendriks, H. A. Schols, and W. J. J. Gerrits. 2015a. Fermentation in the small intestine contributes substantially to intestinal starch disappearance in calves. J. Nutr. 145:1147-1155.

Gilbert, M. S., J. J. G. C. van den Borne, H. Berends, A. J. Pantophlet, H. A. Schols, and W. J. J. Gerrits. 2015b. A titration approach to identify the capacity for starch digestion in milk-fed calves. Animal 9:249-257.

Hediger, M. A., and D. B. Rhoads. 1994. Molecular physiology of sodium-glucose cotransporters. Physiol. Rev. 74:993-1026.

Höber, R., and J. Höber. 1937. Experiments on the absorption of organic solutes in the small intestine of rats. J. Cell. Comp. Physiol. 10:401-422.

Hostettler-Allen, R. L., L. Tappy, and J. W. Blum. 1994. Insulinresistance, hyperglycemia, and glucosuria in intensively milk-fed calves. J. Anim. Sci. 72:160-173.

Hugi, D., R. M. Bruckmaier, and J. W. Blum. 1997. Insulin resistance, hyperglycemia, glucosuria, and galactosuria in intensively milk-fed calves: Dependency on age and effects of high lactose intake. J. Anim. Sci. 75:469-482.

ISO. 1998. Animal feeding stuffs, animal products, and feaces or urine - Determination of gross calorific value - Bomb calorimeter method. ISO 9831. International Organization for Standardization, Geneva, Switzerland.

ISO. 1999a. Animal feeding stuffs - Determination of fat content. ISO 6492. International Organization for Standardization, Geneva, Switzerland.

ISO. 1999b. Animal feeding stuffs. Determination of moisture and other volatile matter content. ISO 6496. International Organization for Standardization, Geneva, Switzerland.

ISO. 2002. Animal feeding stuffs - Determination of crude ash. ISO 5984. International Organization for Standardization, Geneva, Switzerland.

ISO. 2005. Animal feeding stuffs-Determination of nitrogen content and calculation of crude protein content-Part 2: block digestion/ steam distillation method. ISO 5983-2. International Organization for Standardization, Geneva, Switzerland.

Kato, T., Y. Hayashi, K. Inoue, and H. Yuasa. 2005. Glycerol absorption by $\mathrm{Na}^{+}$-dependent carrier-mediated transport in the closed loop of the rat small intestine. Biol. Pharm. Bull. 28:553-555.

Kenward, M. G., and J. H. Roger. 1997. Small sample inference for fixed effects from restricted maximum likelihood. Biometrics 53:983-997.

Kurz, M. M., and L. B. Willett. 1992. The clearance of carbon-14-fructose, carbon-14-glucose, and carbon-14-sorbitol by calves at birth and 7 days of age. J. Dairy Sci. 75:236-246.

Labussière, E., G. Maxin, S. Dubois, J. van Milgen, G. Bertrand, and J. Noblet. 2009. Effect of feed intake on heat production and protein and fat deposition in milk-fed veal calves. Animal 3:557-567.

Le Huerou, I., P. Guilloteau, C. Wicker, A. Mouats, J. A. Chayvialle, C. Bernard, J. Burton, R. Toullec, and A. Puigserver. 1992. Activity distribution of seven digestive enzymes along small intestine in calves during development and weaning. Dig. Dis. Sci. 37:40-46.

Livesey, G. 1991. Calculating the energy values of foods: towards new empirical formulae based on diets with varied intakes of unavailable complex carbohydrates. Eur. J. Clin. Nutr. 45:1-12.

Mayes, P. A. 1993. Intermediary metabolism of fructose. Am. J. Clin. Nutr. 58(Suppl.):754S-765S.

Pereira, J. N., and N. O. Jangaard. 1971. Different rates of glucose and fructose metabolism in rat liver tissue in vitro. Metabolism $20: 392-400$.

Rippe, J. M., and T. J. Angelopoulos. 2013. Sucrose, high-fructose corn syrup, and fructose, their metabolism and potential health effects: What do we really know? Adv. Nutr. 4:236-245. 
Siddons, R. C., R. H. Smith, M. J. Henschel, W. B. Hill, and J. W. G. Porter. 1969. Carbohydrate utilization in the pre-ruminant calf. Br. J. Nutr. 23:333-341.

Swanson, J. E., D. C. Laine, W. Thomas, and J. P. Bantle. 1992. Metabolic effects of dietary fructose in healthy subjects. Am. J. Clin. Nutr. 55:851-856.

Tappy, L., J. P. Randin, J. P. Felber, R. Chiolero, D. C. Simonson, E. Jequier, and R. A. DeFronzo. 1986. Comparison of thermogenic effect of fructose and glucose in normal humans. Am. J. Physiol. 250:E718-E724.

Teff, K. L., J. Grudziak, R. R. Townsend, T. N. Dunn, R. W. Grant, S. H. Adams, N. L. Keim, B. P. Cummings, K. L. Stanhope, and P. J. Havel. 2009. Endocrine and metabolic effects of consuming fructose- and glucose-sweetened beverages with meals in obese men and women: Influence of insulin resistance on plasma triglyceride responses. J. Clin. Endocrinol. Metab. 94:1562-1569.

Toofanian, F., F. W. G. Hill, and D. E. Kidder. 1973. The mucosal disaccharidases in the small intestine of the calf. Ann. Rech. Vet. 4:57-69.

van den Borne, J. J. G. C., G. E. Lobley, M. W. A. Verstegen, J. M. Muijlaert, S. J. J. Alferink, and W. J. J. Gerrits. 2007. Body fat deposition does not originate from carbohydrates in milk-fed calves. J. Nutr. 137:2234-2241.

van den Borne, J. J. G. C., J. M. A. J. Verdonk, J. W. Schrama, and W. J. J. Gerrits. 2006a. Reviewing the low efficiency of protein utilization in heavy preruminant calves - A reductionist approach. Reprod. Nutr. Dev. 46:121-137.

van den Borne, J. J. G. C., M. W. A. Verstegen, S. J. J. Alferink, R. M. M. Giebels, and W. J. J. Gerrits. 2006b. Effects of feeding frequency and feeding level on nutrient utilization in heavy preruminant calves. J. Dairy Sci. 89:3578-3586.

van Es, A. J. H., H. J. Nijkamp, E. J. van Weerden, and K. K. van Hellemond. 1967. Energy, carbon and nitrogen balance experiments with veal calves. Pages 197-201 in Energy Metabolism of Farm Animals. K. L. Blaxter, J. Kielanowski, and G. Thorbek, ed. Oriel Press, Newcastle-upon-Tyne, UK.

Velu, J. G., K. A. Kendall, and K. E. Gardner. 1960. Utilization of various sugars by the young dairy calf. J. Dairy Sci. 43:546-552.

Verstegen, M. W. A., and A. Hoogerbrugge. 1987. Climatic condition and health in young farm-animals. Tijdschr. Diergeneeskd. 112:1062-1068.

Vicari, T., J. J. G. C. van den Borne, W. J. J. Gerrits, Y. Zbinden, and J. W. Blum. 2008a. Postprandial blood hormone and metabolite concentrations influenced by feeding frequency and feeding level in veal calves. Domest. Anim. Endocrinol. 34:74-88.

Vicari, T., J. J. G. C. van den Borne, W. J. J. Gerrits, Y. Zbinden, and J. W. Blum. 2008b. Separation of protein and lactose intake over meals dissociates postprandial glucose and insulin concentrations and reduces postprandial insulin responses in heavy veal calves. Domest. Anim. Endocrinol. 34:182-195.

Werner-Omazic, A., M. Tråvén, S. Roos, E. Mellgren, and K. Holtenius. 2013. Oral rehydration solution with glycerol to dairy calves: effects on fluid balance, metabolism, and intestinal microbiota. Acta Agric. Scand. Anim. Sci. 63:47-56.

Zhao, F. Q., E. K. Okine, C. I. Cheeseman, S. P. Shirazi-Beechey, and J. J. Kennelly. 1998. Glucose transporter gene expression in lactating bovine gastrointestinal tract. J. Anim. Sci. 76:2921-2929. 